\title{
Propertology as An Educational Discipline: Is It in Demand by Modern Universities?
}

\author{
Andrey Orekhov \\ Department of Social Philosophy \\ Peoples' Friendship University of Russia \\ Moscow, Russia \\ E-mail: orekhovandrey@yandex.ru
}

\author{
Aleksey Neugodnikov \\ NPK "Monitoring-Tsentr" \\ Moscow, Russia \\ E-mail: neugodnikovap2016@yandex.ru
}

\begin{abstract}
Actual research in the social sciences requires the establishment of the new interdisciplinary areas which may also include propertology-interdisciplinary research dedicated to property. The sections of propertology are a philosophy of property, an economy of property, sociology of property, a right of property, a political theory of property etc. The propertology course shall be taught as part of interdisciplinary academic disciplines, such as political philosophy, philosophy of economics, economic sociology, etc.
\end{abstract}

Keywords-propertology; academic discipline; education; university

\section{INTRODUCTION: WHAT IS PROPERTOLOGY?}

"Propertology" is a new interdisciplinary branch of knowledge, developing the interdisciplinary theory of property. The term emerged in A.M. Orekhov and M.V. Skachko's article "The Philosophy of Property as a Prerequisite to Propertology" [3]. Both authors, exploring the current state of sciences studying property, come to conclusion about the necessity of creating a global interdisciplinary science of property - science, that should combine major disciplines, dealing with the subject of property - a philosophy of property, an economy of property, a sociology of property and so on. This science, according to the scholars, should be similar to the so-called "cratology"interdisciplinary teaching on property, proposed by F.V. Khalipov:

"Following the line of [cratology's] reasoning, we would like to put forward an idea,-or, more accurately, a concept, - of a new academic discipline, focused on studying property. This discipline shall be named "propertology" (from English "property" and Ancient Greek "-logos",

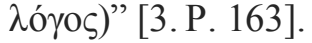

The authors provide the following definition of "propertology":

"Propertology is an interdisciplinary science on property, devoted to exploring property from the various points of view - economical, sociological, philosophical, and so on". [3. P. 163].

Yet, one may provide a slightly different definition of propertology:

"Propertology is a global science on property, revealing intra-disciplinary and transdisciplinary discourses of the said institution, summarizing its social practices, and constructing against this background a universal social theory of property".

This definition point indicates several important characteristics of propertology.

First, this definition emphasizes the "global", "comprehensive", "overall" character of propertology. It encompasses all the aspects, facets of property.

Second, this definition designates the propertology's intention to reveal and analyze not only intra-disciplinary but also transdisciplinary, cross-disciplinary and interdisciplinary discourses on property.

Third, this definition asserts that propertology is not being created in a vacuum but on the basis of social practices built around property, i.e. with the maximal use of empirical, practical material.

The classification of the main sections of propertology is found in "Table I": 
TABLE I.

THE SECTIONS OF PROPERTOLOGY

\begin{tabular}{|l|l|l|}
\hline № & \multicolumn{1}{|c|}{ Sections of Propertology } & \multicolumn{1}{c|}{ Subject of Research } \\
\hline 1 & Philosophy of Property & Global comprehension of the knowledge on property, a methodological analysis of the problem of property \\
\hline 2 & Sociology of Property & Property as a social (sociological) institution, place of property in various stratification models \\
\hline 3 & Economy of Property & $\begin{array}{l}\text { Analysis of property as an economic institution (along with money, cost, labor, capital and so on), property as a } \\
\text { scarce resource of society in the light of "costs/profits" problem }\end{array}$ \\
\hline 4 & Proprietary Rights & The legal norms, governing the treatment of property \\
\hline 5 & Anthropology of Property & $\begin{array}{l}\text { The study of the nature of a subject, owning property, in prospect of future-property - the property of the years to } \\
\text { come }\end{array}$ \\
\hline 6 & Psychology of Property & Psychological attributes of an owner, and mass psychological reactions in the sphere of property \\
\hline 7 & History of Property & $\begin{array}{l}\text { Chronological description of property as an institution development, and the development of notions towards } \\
\text { property }\end{array}$ \\
\hline 8 & Political Theory of Property & Power relations in the sphere of property management and disposal \\
\hline 9 & Gender Theory of Property & The influence of sex and gender on the behavior of the owner \\
\hline 10 & Culturological theory of Property & Property as a cultural value, axiology of property \\
\hline
\end{tabular}

Everything said previously is only one of the possible classifications of approaches to the subject of propertology. The discipline may also be divided into fundamental (theoretical) propertology and applied propertology. Fundamental propertology may be defined as a "general theory of property" with the following distinguished elements:

- Elements of theory - the most fundamental scholar concepts that contribute to the very theory of property ("property rights", "institution", "property", "power", "government", etc.);

- "Ideologemes" and myths in the theory of property ("class conflict", "expropriation of the expropriators", etc.);

- Methodology and epistemology of property, i.e. the cognitive and methodological tools for its researchsupplied by the philosophy of property;

- The "sociology of property"- but not in the sense of some particular science, but as a section of the fundamental propertology, responding to the question "Who and why researches property?").

The tasks of applied propertology are more simple and obvious: these are an empirical study of particular forms of property. It may be, for example, the study of the institution of the municipal property in contemporary Russia, or the study of agricultural property in some African state. Applied propertology delivers actual empirical data for fundamental propertology, as the latter provides methodology and theories.

We can thus conclude that there are all prerequisites today for the establishment of the fundamentally new research area - propertology. This area should consolidate all the efforts of the scholars and scientists, studying property, and thereby help them to find new, unknown frontiers in studying the phenomenon of property.

\section{HISTORY OF PROPERTOLOGY}

Thus, propertology shall revitalize the study of property. However, it is appropriate to ask ourselves, whether there were earlier attempts to do so? Were there in the history of socio-humanitarian thought philosophers, sociologists, economists, who tried to construct a similar science, or at least to offer a similar line of thought?
In our view, there were such attempts, though, infrequent.

First and foremost, we shall note Plato $(427-347$ BC) and Aristotle (384 - 322 BC), two major theorists of ownership in Antiquity. Both of them were developing the following problems in the philosophe and theory of property:

- the separation of property into private and public resulting in social antagonism (Plato was an advocate of public property and allowed private property for the lower classes only; Aristotle, on the contrary, advocated the primacy of private property over the public one);

- the allocation of the two functions of property possession and exploitation (this found in Aristotle's works, primarily);

- the "justification" of the need of property institution at all (here Plato and Aristotle agreed with each other)

- the requirement (as in Plato, so Aristotle) for the developing of axiological, "cultural" aspects of the theory of property, and the problem of the ethics of an owner.

Another example is John Locke (1632 - 1704), notable English philosopher, economist, and historian. His work the "Two Treatises of Government" is interesting for us primarily because of the labor concept of property's origin and "justification", put forward by the English philosopher. The concept may generally be described using the following statements:

"Labor, and labor alone, creates property. Labor, and labor alone, justifies the existence of property". Or, to quote Locke himself, "it [labor] adds to them [the fruits of the land] something beyond that the nature, the mother of all, created and, thus, they become a private property" [2. P. 277] or: "labor approved my property to them" [2. P. 278].

The other side of the Locke's doctrine on property is the affirmation of private property as the basis of property at large. The English philosopher states:

"God, who hath given the world to men in common, hath also given them reason to make use of it to the best advantage of life, and convenience". [2. P. 280]. "Though the earth, and all inferior creatures, be common to all men, yet every man has a property in his own person: this no body has any right to but himself. The labour of his body, and the 
work of his hands, we may say, are properly his" [2. P. 281]. "Though the water running in the fountain be every one's, yet who can doubt, but that in the pitcher is his only who drew it out? His labour hath taken it out of the hands of nature, where it was common, and belonged equally to all her children, and hath thereby appropriated it to himself" [2. P. 278].

Thus, the general conclusion from the Locke's teaching on property may be stated the following way: private property is necessary and justified if it is created by labor; private property shall always form the basis of economic life in a state.

The last but not the least example is the German philosopher G.W.F. Hegel (1770 - 1831), who should be considered not only as an influential philosopher or a specialist in the field of property rights, but also as the largest propertologist. In his works, especially in "Elements of the Philosophy of Right", he summed up and deepened the contemporary concept of property and justified the "legal philosophical" approach to property, which became a classic approach in the European law.

According to Hegel, property is a form of the objectification of the mind.

"The reasonableness of property consists not in its satisfying our needs, but in its superseding and replacing the subjective phase of personality. It is in possession first of all that the person becomes rational" [1. P. 101]. To "appropriate" property means to bend it to one's will: "To appropriate is at bottom only to manifest the majesty of my will towards things, by demonstrating that they are not selfcomplete and have no purpose of their own. This is brought about by my instilling into the object of another end than that which it primarily had" [1. P. 104]. The need for private property comes from the availability and possibility of the own will objectification towards the things: "In property my will is personal. But the person, it must be observed, is this particular individual, and, thus, property is the embodiment of this particular will. Since property gives visible existence to my will, it must be regarded as "this" and hence as "mine". This is the important doctrine of the necessity of private property. If exceptions may be made by the state, the state alone can be suffered to make them" [1. P. 105].

Hegel also opposes the utopian ideas of universal equality:

"What and how much I possess is from the standpoint of right a matter of indifference" [1. P. 107]. "Hence the assertion that the property of every man ought in justice to be equal to that of every other is false, since justice demands merely that every one should have property. Indeed, amongst persons variously endowed inequality must occur, and equality would be wrong" [1. P. 108].

Hegel, however, no less categorically rejects, e.g., the possession of an individual by another individual (i.e. slavery), as from the standpoint of the German thinker, the individual should be viewed not as a natural creature, but as a "spirit, free in self":
"If we hold fast to the side that man is absolutely free, we condemn slavery" [1. P. 114].

All in all, we would like to state: propertology has not only the right to exist; it also has its own history. The history of various sciences on property has, largely, produced the phenomenon of propertology Plato, Aristotle, Locke, Hegel - we should and ought to consider these thinkers to be the first "propertologists", although, of course, the science didn't exist back then.

\section{PROPERTOLOGY AS AN EDUCATIONAL Discipline}

Does a modern university need a course on propertology?

Let us firstly decide on the typology of the course. It is obvious, that the course is not mono-disciplinary, but interdisciplinary, i.e. basing on various disciplines: philosophy, economy, sociology, political science and so on. Whether the interdisciplinary course on propertology be needed for, e.g., a sociologist or an economist?

Probably not. Average sociology students and doctoral students will have enough knowledge on property, obtained during the courses in, e.g., economic sociology or economic theory. The whole other thing is students and doctoral students, who choose as their learning profiles such fields of knowledge as "economic sociology", "institutional economics", or "economy and law". Since all these fields are interdisciplinary, the course on propertology as a fundamental academic discipline dedicated specifically to property will not only be desirable, but even necessary. For example, the doctoral law student, specializing in civil, land or commercial law, looking forward to engage in the realty deals, as we believe, might benefit not only from the knowledge of the right of property, but also from the psychology, sociology and even philosophy of property: this will expand his intellectual horizon and allow him to comprehend many things in terms of property much deeper compared to his colleagues or cases.

And as briefly, how the exemplary course on propertology might look like?

The course, we believe, should consist of eight major sections, estimated to the standard 36 hours ( 4 hours per each section: 2 hours for a lecture, 2 hours for a seminar).

- The Object of Propertology.

- Philosophy of Property as the First Premise of Propertology.

- Economic Theory of Property.

- Proprietary Rights: Russian and International Experience.

- Property as a Social Institution: Sociology of Property.

- Psychology, Anthropology and Other Sections of Property.

- Fundamental and Applied Propertology.

- Prospects for the Propertology Development. 
In our opinion, the course on propertology may be in demand in the modern-day Russian universities and could be taught in various interdisciplinary academic areas, such as "political philosophy", "philosophy of economics", "economic sociology" etc.

\section{CONCLUSION}

To what conclusions we have come to the end of our discussion?

- Propertology is a global science about property, revealing intra- and transdisciplinary discourses of the said institution, summarizing its social practices, and constructing on its basis the universal social theory of property.

- The sections of propertology are: philosophy of property, economy of property, sociology of property, right of property, political theory of property, etc.

- The greatest "propertologists" of the past are Plato Aristotle, John Locke, Georg Wilhelm Friedrich Hegel and some others.

- The course of propertology may in fact be in demand in the modern-day Russian universities and may be taught in various interdisciplinary areas, such as "law and economy", "institutional economy", "economic sociology", etc.

\section{REFERENCES}

[1] G.W.F .Hegel. Elements of the Philosophy of Right, Moscow, Mysl'.1990.

[2] J. Locke. Works in Three Volumes, vol.3. Moscow, Mysl'.1988.

[3] A.M.Orekhov, M.V.Skachko. Philosophy of Property as the First Premise of Propertology // Vestnik RUDN ("Filosofija"), Moscow: vol.1, P.163-175. 2015. 